\title{
Short-term variations in flow velocity of Glaciar Soler, Patagonia, Ghile
}

\author{
RENJi NARUSE, \\ Institute of Low Temperature Science, Hokkaido University, Sapporo 060, Japan \\ Hiroshi Fukami, \\ Geological Survey of Hokkaido, Sapporo 060, Japan \\ MASAMU ANIYA \\ Institute of Geoscience, University of Tsukuba, Ibaraki 305, Japan
}

\begin{abstract}
Short-term variations in ice-flow velocity were obtained at intervals of a few hours and a few days in the ablation area of Glaciar Soler, Patagonia, Chile, in November 1985. A maximum flow rate was measured at about four times the minimum value. A good correlation, with a time lag of $7.5 \mathrm{~h}$, was found between the ice-flow velocity in the lower reaches and the amount of water discharge from the glacier terminus. It was concluded, therefore, that the velocity variations should have resulted from the variations in basal sliding velocity which is strongly controlled by the subglacial water pressure.
\end{abstract}

\section{INTRODUCTION}

Short-term variations in flow velocity have been extensively studied at various glaciers with relatively easy access in the world; for example, Switzerland (Iken, 1978), Alaska (Kamb and others, 1985; Vaughn and others, 1985) and Sweden (Jansson and Hooke, 1989). Emphasizing the water pressure at the glacier bed, these studies have provided an important insight into understanding the mechanisms and characteristics of glacier variations and surge phenomena.

The Patagonia region extends in a strip from $42^{\circ}$ to $55^{\circ} \mathrm{S}$ over the southern part of South America. There are two large ice fields in Patagonia, commonly referred to as Hielo Patagònico Norte and Sur (inset in Figure 1). Numerous outlet glaciers discharge from the ice fields in all directions downstream. Patagonian glaciers are characterized by a large amount of precipitation and high rates of ablation due to ice melt and calving into fjords or lakes throughout the year.

Prior to the early 1980s, only a few crude studies had been attempted on the ice flow of Patagonian glaciers, using aerial photographs (Lliboutry, 1956), by simple survey methods (e.g. Marangunić, 1964; Naruse and Endo, 1967) or by triangulation surveys (Naruse, 1985). More detailed measurements of ice-flow velocities were carried out in the ablation area of Glaciar Soler from October to November 1985 (Naruse, 1987). The purpose of this paper is to present the results of the ice-flow velocity measurements using short intervals of either a few hours or a few days, and to discuss the velocity variations in the light of the observed hydrological and meteorological phenomena. This study provides important data from an area where no such research has hitherto been done.

\section{THE STUDY AREA - GLACIAR SOLER}

Glaciar Soler (Fig. 1) is located on the eastern side of Hielo Patagònico Norte, with the present terminus position at $46^{\circ} 54^{\prime} \mathrm{S}, 73^{\circ} 11^{\prime} \mathrm{W}$ and about $300 \mathrm{~m}$ a.s.l. The ablation area forms a valley-type glacier, on average about $8 \mathrm{~km}$ long and $1.5 \mathrm{~km}$ wide. The equilibrium line was estimated at about $1350 \mathrm{~m}$, just above the icefalls. Of the total accumulation area $\left(36 \mathrm{~km}^{2}\right)$, about $28 \mathrm{~km}^{2}$ lies in the ice field, while the remainder lies on the southeastern slope of Cerro Hyades (Aniya and others, 1988). The southern half of the ablation area consists of debris-free ice discharged from the ice field, while the northern half, which is fed by avalanches from Cerro Hyades, is covered with till.

A longitudinal profile of the surface of the ablation area is shown in Figure 2c, together with bedrock profiles estimated from gravimetric surveys (Casassa, 1987). The transverse profile at point $\mathrm{S} 5$ indicates that a subglacial ridge is located near the center. A large amount of water is drained through a subglacial tunnel at the glacier terminus of debris-free ice.

\section{METHOD OF MEASUREMENT}

Three control stations, $\alpha, \beta$ and $\gamma$, were established (Fig. 1) and the distances between them were measured using an electronic distance meter (Topcon EDM-Theodolite 


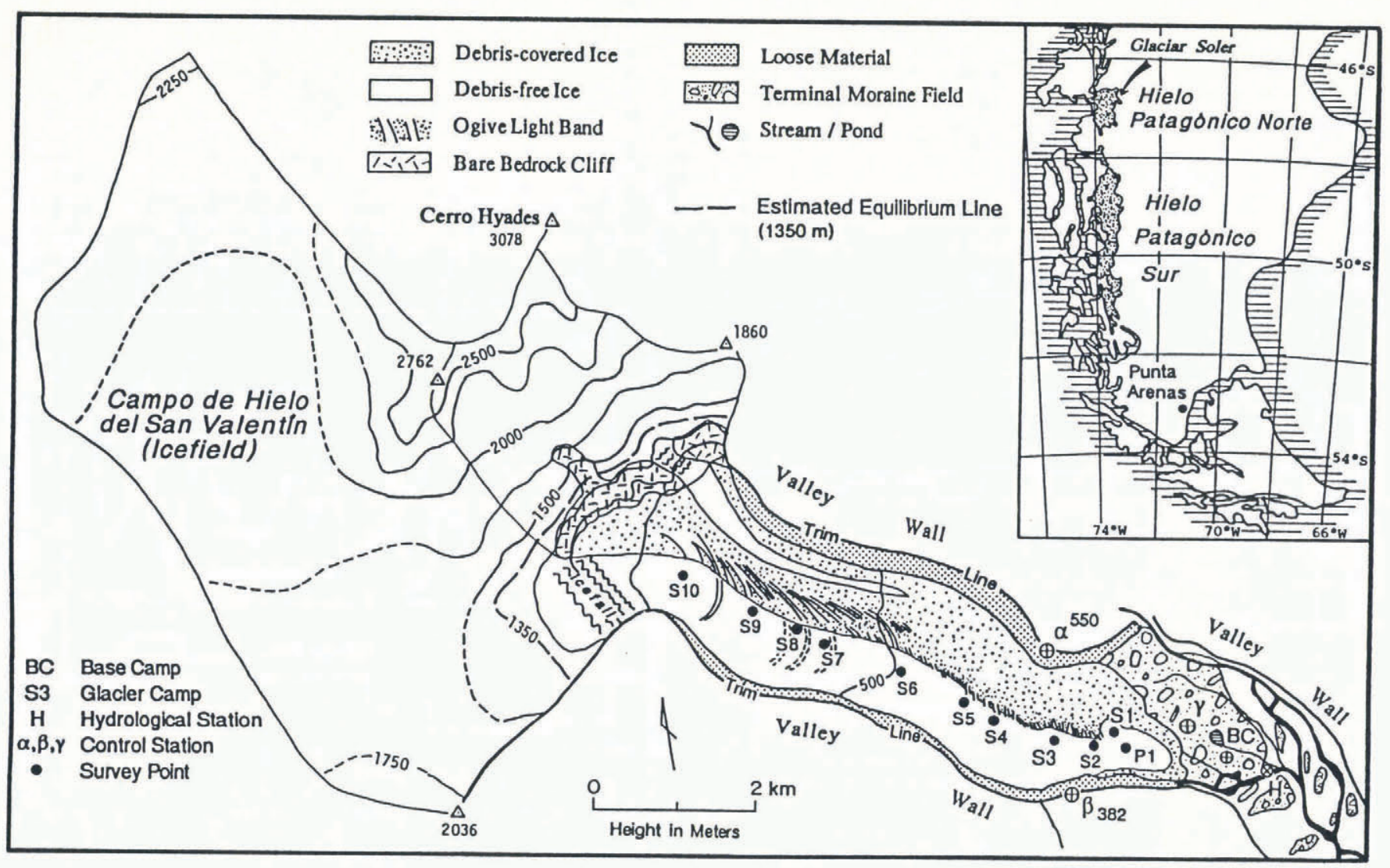

Fig. 1. The drainage area of Glaciar Soler with the locations of control stations and survey points. Inset: location of Hielo Patagònico Norte and Sur (northern and southern Patagonia ice fields) in South America.

Guppy GTS-2). Coordinates of survey points on the glacier were determined by triangulation surveys from these stations. Short-interval measurements of ice flow were carried out for point S1 from station $\gamma$ with the distance meter, in which the observation line was approximately parallel to the ice-flow direction.

A hydrological station $\mathrm{H}$ was set up in the water stream $1.3 \mathrm{~km}$ downstream from the glacier terminus (Fig. 1 ), and the amount of water discharge from the glacier was continuously monitored using a float-type water gauge. Measurements of electrical conductivity and $\mathrm{pH}$ were also made in situ. Sampling of water was occasionally made at $\mathrm{H}$ and other points in the drainage system, and dissolved substances were analysed in the laboratory (Fukami and Escobar, 1987). The catchment area of station $\mathrm{H}$ is estimated to be $81 \mathrm{~km}^{2}$, about $64 \%$ of which is ice-covered.

Daily ablation rates were measured using a stake method at six selected points (Fukami and Naruse, 1987). Air temperature was measured at point S3, and global (shortwave) radiation and precipitation were observed continuously at the base camp (BC), $1 \mathrm{~km}$ downstream from the glacier terminus (Fukami and others, 1987).

\section{RESULTS OF MEASUREMENTS}

\section{Distribution of flow velocities}

The longitudinal distribution of flow velocities along the centre line of the ablation area is shown in Figure 2a. These velocities indicate mean values over $5-16 \mathrm{~d}$ in October-November 1985. After a sharp drop in the velocity below the icefall, it decreases gradually downglacier. Also shown in Figure $2 \mathrm{~b}$ are the longitudinal strain rates obtained from the surface-velocity gradients. A mean strain rate, about $-3 \times 10^{-4} \mathrm{~d}^{-1}\left(-0.1 \mathrm{a}^{-1}\right)$, indicates a much larger compression than that normally observed in mountain glaciers (e.g. Paterson, 1981). Since the width of the glacier is almost constant over the ablation area, the transverse strain rate can be regarded as negligibly small. Then, from a continuity condition of incompressible ice, a vertical strain rate can be estimated at about $+0.1 \mathrm{a}^{-1}$. Assuming a mean thickness of the glacier ice as $300 \mathrm{~m}$ (Fig. 2 ), the strain rate would correspond to $30 \mathrm{~m} \mathrm{a}^{-1}$ of the emergence component of ice flow. The annual amount of ablation is then taken as this order of magnitude, if we assume a steady-state condition.

\section{Short-term variations in glacier flow}

Variation in ice-flow velocity was obtained from the repetitive measurements at point $\mathrm{Sl}$, as shown in Figure $3 a$. The mean velocity was relatively low because of the proximity of S1 to the glacier terminus; yet, the velocity varied considerably within a short time. Velocity variations were also obtained at points P1, S2 and S3 by angular measurements with intervals of a few days or a half day in the summers of 1983 and 1985. The velocity at S3 changed greatly from day to day, with the maximum being six 
(a)
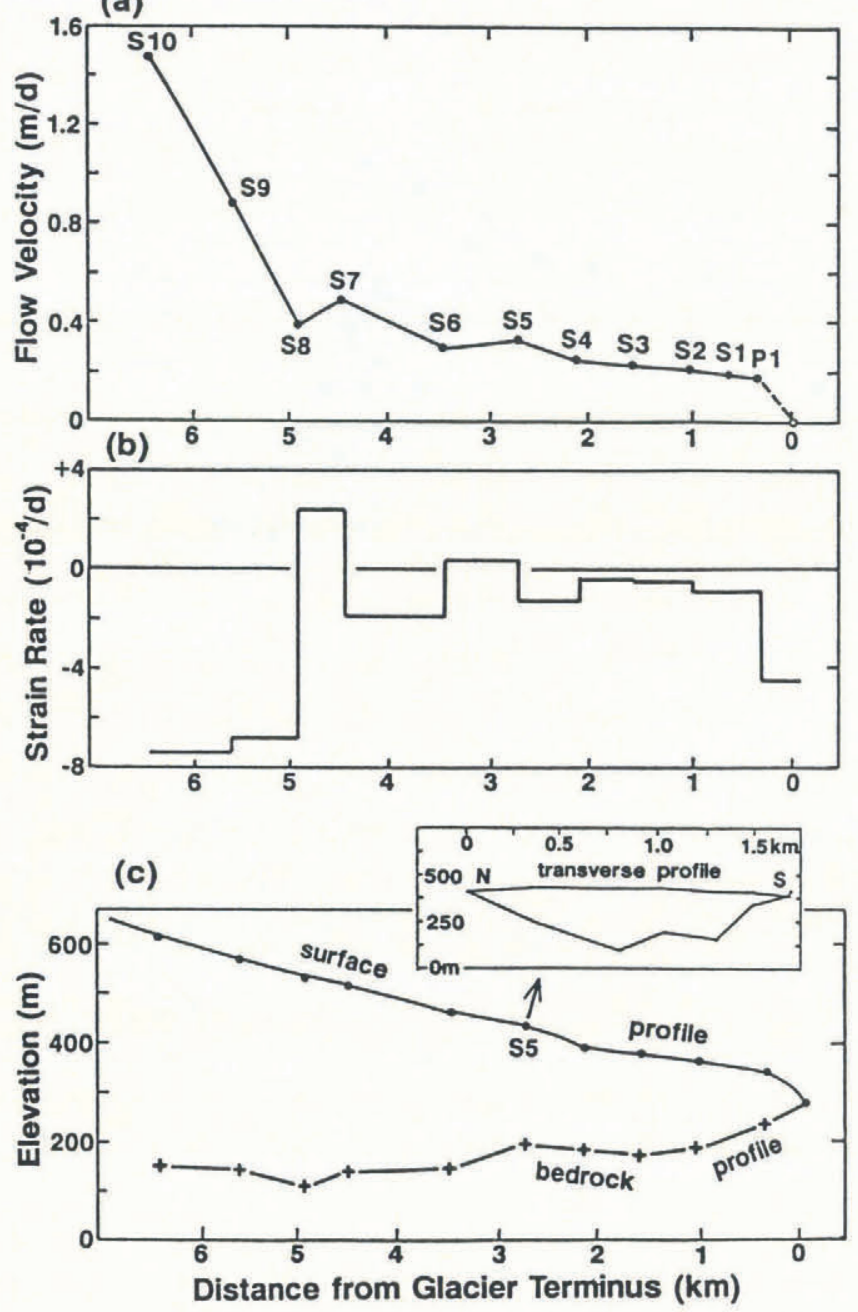

Fig. 2. Longitudinal profiles along the approximate centre line of Glaciar Soler: (a) surface-flow velocity measured with intervals of 5-15d in October-November 1985; (b) longitudinal strain rate at the glacier surface; (c) glacier surface and bedrock surface deduced from gravity values.

times larger than the minimum, whereas the velocities at P1 and S2 fluctuated even less, but greatly exceeding the range of the measurement errors.

The intrinsic error in the distance meter used for the measurement of point $\mathrm{S} 1$ is about $2 \mathrm{~mm}$. Since the tripod of the reflector was buried firmly in the surface ice at S1, the error due to tilting of the reflector is almost negligible. The direction of the ice flow at $\mathrm{S} 1$ deviates only $13^{\circ}$ from the direction of S1 to $\gamma$, so that a displacement of S1 can be obtained from the measured distances corrected by a small factor. Considering these error components, the total error involved in the displacement of the point can be assumed to be $1 \mathrm{~cm}$ at a maximum. Then an error in the short-term $(3 \mathrm{~h})$ velocity would be about $3 \mathrm{~mm} \mathrm{~h}^{-1}$. Hence, velocity variations greater than $3 \mathrm{~mm} \mathrm{~h}^{-1}$ in Figure $3 \mathrm{a}$ should be regarded as valid.

\section{Meteorological and hydrological data}

Some meteorological and hydrological data are also shown in Figure 3. Each ablation rate was derived by averaging six data sets, three from the debris-free ice (surface albedo $0.42-0.44)$ and three from the ice covered with small

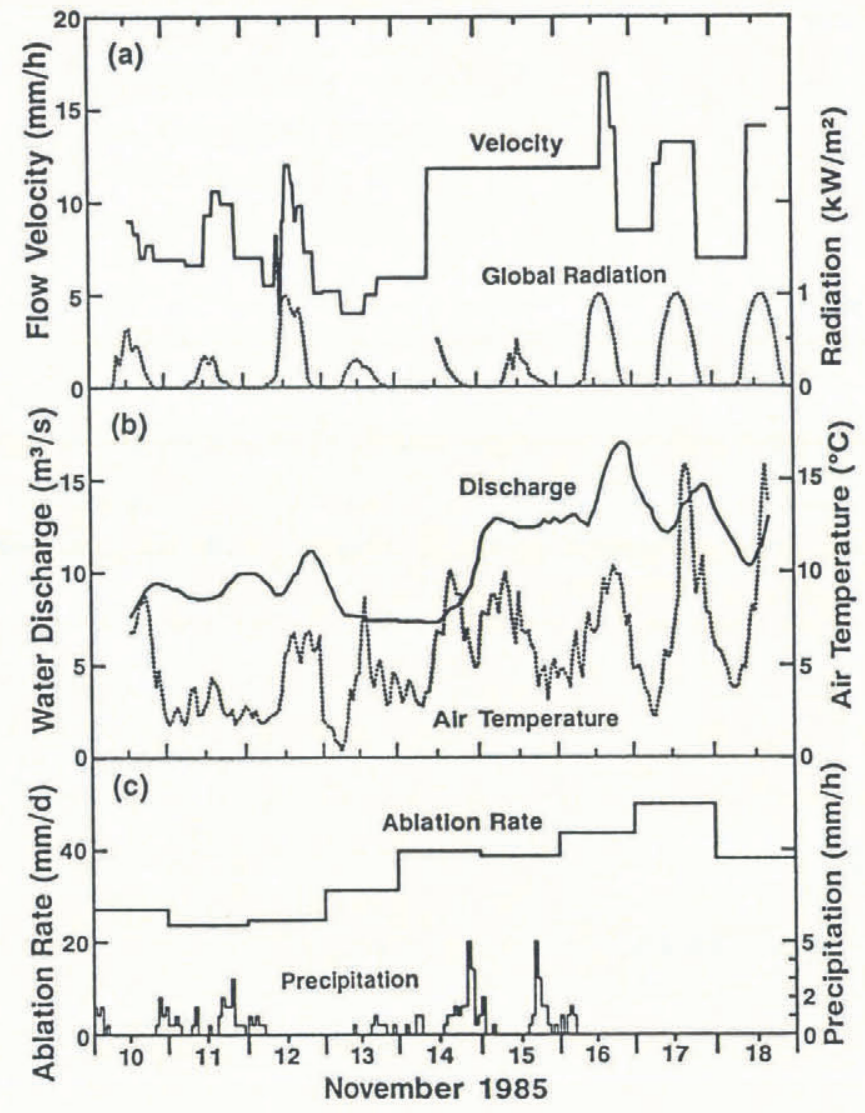

Fig. 3. (a) Variations in the surface-flow velocity at point S1 near the glacier terminus, and the amount of global radiation measured at $B C ;(b)$ water discharge measured at station $\mathrm{H}$ and air temperature at S3; (c) ablation rate (in water equivalent) averaged over six points in the ablation area and the amount of precipitation at BC in November 1985.

pebbles and/or fine sand $0.5-3 \mathrm{~cm}$ in thickness (albedo 0.09-0.11). The components of the heat source causing melting of the debris-free ice were calculated to be about $65 \%$ for the radiative balance and $35 \%$ for the sensible heat during the observation period.

\section{DISCUSSION}

\section{Relation between ice-flow velocity and meteorological-hydrological parameters}

In Figure 3, it appears that there is a high correlation between peaks of the ice-flow velocity at point $\mathrm{S} 1$ and of global radiation or air temperature. However, at point $\mathrm{S} 3$ such a tendency cannot be recognized. From a close examination of the various parameters measured in the field, the best correlation was found between the ice-flow velocity at $\mathrm{S} 1$ and the amount of water discharge at station $\mathrm{H}$. Figure 3 suggests a time lag between the peaks of the velocity and the water discharge. A time lag of $7.5 \mathrm{~h}$ was obtained from calculation of the auto-correlation between them every $0.5 \mathrm{~h}$, with a correlation coefficient of 0.85 . From this analysis, we conclude that the flow velocity is strongly related to the amount of water discharged from the glacier. 


\section{Predominance of basal sliding}

We can point out in Figure 3 that the largest flow rate (c. $16 \mathrm{~mm} \mathrm{~h}^{-1}$ ) is about four times the smallest (c. 4 $\mathrm{mm} \mathrm{h}^{-1}$ ). The flow velocity measured at the glacier surface is the sum of velocities caused by plastic deformation, basal sliding and fracture of the ice body. The first mechanism cannot be considered to vary within a short period of time. The third one may be possible at Glaciar Soler which has many crevasses and seracs (Jacobel, 1982). However, if this is a dominant factor causing the velocity variation, the directions of ice flow should vary with time according to the widening or narrowing of crevasses and cracks. In Glaciar Soler, any significant change in the flow direction was not observed. Consequently, it appears best to attribute the observed variations in velocity to variations in basal sliding.

Such phenomena have recently been observed and analysed in various glacial areas. The first extensive work was by Iken (1978), who measured surface movements during intervals of $4-12 \mathrm{~h}$ at four glaciers in the Alps and showed a time lag between velocity maxima and waterdischarge maxima in the river downstream. Iken (1981) then proposed the effect of subglacial water pressure on sliding velocity based on an idealized numerical model. At Findelengletscher, the basal water pressure was measured in 11 boreholes and an empirical relationship was obtained between the water pressure and flow velocity (Iken and Bindschadler, 1986). During the mini-surges of Variegated Glacier, Alaska, strong variations in velocity were obtained within short periods, and their relation to the basal water systems was discussed (Kamb and others, 1985; Kamb and Engelhardt, 1987). Short-term variations in velocity have also been reported from Columbia Glacier, Alaska (Vaughn and others, 1985), and in strain and surface tilt from a northern Swedish glacier (Jansson and Hooke, 1989). Today, the importance of basal water pressure is fully recognized in the study of basal sliding and surge phenomena of glaciers.

\section{Englacial and subglacial water system}

The electrical conductivity measured at station $\mathrm{H}$ was almost inversely proportional to the amount of water discharge, varying from 5 to $9 \mu \mathrm{S} \mathrm{cm}^{-1}$ (at $0^{\circ} \mathrm{C}$ ) with a correlation coefficient of -0.93 . Since the conductivity of the supraglacial water was $0.00 \mu \mathrm{S} \mathrm{cm}^{-1}$, this inverse relation must be caused by an increase in meltwater to the discharge at station $\mathrm{H}$. We now roughly evaluate the contribution of the meltwater from glacier ice to the total discharge based on the data shown in Figure 3. The mean ablation rate during this period was about $40 \mathrm{~mm} \mathrm{~d}^{-1}$. Multiplying this amount by the ablation area $15 \mathrm{~km}^{2}$, we obtain the daily total amount of water, $6 \times 10^{5} \mathrm{~m}^{3} \mathrm{~d}^{-1}$, which corresponds to $7 \mathrm{~m}^{3} \mathrm{~s}^{-1}$ of water discharge. At station $\mathrm{H}$, the mean water discharge during that period was about $11 \mathrm{~m}^{3} \mathrm{~s}^{-1}$. The rest of the water, about $30 \%$, should be supplied by melting of snow in the accumulation area, by precipitation in the drainage basin, and also by five incoming streams on the right bank.

Numerous supraglacial water streams were formed in the ablation area during fine and warm weather conditions, and most of them terminated at moulins, crevasses or ponds. Since the water level in such crevasses and ponds always remained below the glacier surface, we can suppose that these water intakes are connected with the englacial and subglacial water channels. Abundance of rounded gravel and sand in the end moraines (Aniya, 1987) also suggests very active and well-developed subglacial streams. The component ratio of dissolved substances measured at station $\mathrm{H}$ differed from those at other points in the drainage system. For example, the composition at station $\mathrm{H}$ was characterized by enrichment in $\mathrm{K}^{+}\left(0.77 \mathrm{mg} \mathrm{l}^{-1}\right)$, while that at an incoming stream near station $\beta$ was $0.24 \mathrm{mg} \mathrm{l}^{-1}$. The compositions of other cations were almost the same at both sites. Since supraglacial and englacial streams have virtually no dissolved substances, the water at station $\mathrm{H}$ cannot be considered to be a simple mixture of incoming stream water and supraglacial and englacial ones. The property of enrichment in $\mathrm{K}^{+}$ probably originates from the subglacial bed.

Based on this evidence, we can conclude that a major part of the total amount of water produced at the glacier surface should be drained through the subglacial water system. Hence, the amount of discharge at station $\mathrm{H}$ can be considered as strongly reflecting the amount of subglacial water. Although we have no information about the suglacial water network, it is reasonable to suppose that the high amount of subglacial water discharge is accompanied by an increase in the thickness of the water layer at the bed and/or by an increase in the pressure of basal water channels. We therefore conclude that the high surface velocity can be attributed to basal sliding accelerated by the existence of abundant water at the glacier bed. The water is supplied mostly by melting of surface ice and also by the heavy precipitation. The time lag, $7.5 \mathrm{~h}$, can be interpreted as the apparent travel time of the water mass along a distance of about $2 \mathrm{~km}$ from station $\mathrm{S} 1$ to $\mathrm{H}$. If we regard the minimum observed velocity as due to the plastic deformation of the ice body, basal sliding accounts for approximately three-quarters of the surface velocity near the terminus during the spring season.

\section{CONCLUSIONS}

Short-term variations in ice-flow velocity were obtained in the ablation area of Glaciar Soler in November 1985. Based on the strong correlation between the ice-flow velocity and the amount of water discharged from the glacier terminus with a certain time lag, it can be concluded that the velocity variations have resulted from variations in basal sliding velocity, which is greatly influenced by the amount of water draining through the subglacial water system. The water is mostly supplied by melting of surface ice dominantly due to absorbed global radiation and also by precipitation over the entire drainage basin during heavy rains.

\section{ACKNOWLEDGEMENTS}

We should like to thank F. Escobar of Direcciòn General de Aguas in Chile and G. Casassa of the Ohio State University for the field assistance. This study was supported by grants from the International Scientific 
Research Program of the Ministry of Education, Science and Culture, Japan.

\section{REFERENCES}

Aniya, M. 1987. Moraine formation at Soler glacier, Patagonia. Bull. Glacier Res. 4, 107-117.

Aniya, M., G. Casassa and R. Naruse. 1988. Morphology, surface characteristics, and flow velocity of Soler glacier, Patagonia. Arct. Alp. Res., 20(4), 414-421.

Casassa, G. 1987. Ice thickness deduced from gravity anomalies on Soler glacier, Nef glacier and the northern Patagonia icefield. Bull. Glacier Res. 4, 43-57.

Fukami, H. and F. Escobar. 1987. Hydrological characteristics in Soler glacier drainage, Patagonia. Bull. Glacier Res. 4, 91-96.

Fukami, H. and R. Naruse. 1987. Ablation of ice and heat balance on Soler glacier, Patagonia. Bull. Glacier Res. 4, $37-42$.

Fukami, H., F. Escobar, J. Quinteros, G. Casassa and R. Naruse. 1987. Meteorological measurements at Soler glacier, Patagonia, in 1985. Bull. Glacier Res. 4, 31-36.

Iken, A. 1978. Variations of surface velocities of some Alpine glaciers measured at intervals of a few hours. Comparison with Arctic glaciers. Z. Gletscherkd. Glazialgeol., 13(1/2), 1977, 23-35.

Iken, A. 1981. The effect of the subglacial water pressure on the sliding velocity of a glacier in an idealized numerical model. F. Glaciol., 27(97), 407-421.

Iken, A. and R. A. Bindschadler. 1986. Combined measurements of subglacial water pressure and surface velocity of Findelengletscher, Switzerland: conclusions about drainage system and sliding mechanism. $\mathcal{J}$. Glaciol., 32(110), 101-119.

Jacobel, R. W. 1982. Short-term variations in velocity of
South Cascade Glacier, Washington, U.S.A. J. Glaciol., 28(99), 325-332.

Jansson, P. and R. LeB. Hooke. 1989. Short-term variations in strain and surface tilt on Storglaciären, Kebnekaise, northern Sweden. J. Glaciol., 35(120), 201208.

Kamb, B. and H. Engelhardt. 1987. Waves of accelerated motion in a glacier approaching surge: the mini-surges of Variegated Glacier, Alaska, U.S.A. J. Glaciol., 33(113), 27-46.

$\mathrm{Kamb}, \mathrm{B}$. and 7 others. 1985. Glacier surge mechanism: 1982-1983 surge of Variegated Glacier, Alaska. Science, 227(4686), 469-479.

Lliboutry, L. 1956. Nieves y glaciares de Chile. Santiago, Ediciones de la Universidad de Chile.

Marangunić, C. Unpublished. Observaciones glaciológicas y geológicas en la zona del Paso de los Cuatro Glaciares, Hielo Patagónico Sur. Santiago, Universidad de Chile.

Naruse, R. 1985. Flow of Soler glacier and San Rafael glacier. In Nakajima, C., ed. Glaciological studies in Patagonia northern icefield 1983-1984. Nagoya, Japanese Society for Snow and Ice. Data Center for Glacier Research, 64-69.

Naruse, R. 1987. Characteristics of ice flow of Soler glacier, Patagonia. Bull. Glacier Res. 4, 79-85.

Naruse, R. and T. Endo. 1967. Glaciological investigations of northern Patagonian glaciers, Chile. Seppyo, 29(6), 167-176.

Paterson, W. S. B. 1981. The physics of glaciers. Second edition. Oxford, etc., Pergamon Press.

Vaughn, B.H. and 9 others. 1985. Short-term velocity measurements at Columbia Glacier, Alaska: AugustSeptember 1984. U.S. Geol. Surv. Open-file Rep. 85-487.

The accuracy of references in the text and in this list is the responsibility of the authors, to whom queries should be addressed. 